\title{
Pengembangan FIDTI (Fluid Isomorphic Diagnostic Test Inventory) Sebagai Instrumen Diagnostik Miskonsepsi Fluida
}

\author{
Mohammad Zaky Tatsar ${ }^{1}$, Nuril Munfaridah ${ }^{2}$, Markus Diantoro ${ }^{3}$ \\ Jurusan Fisika, Fakultas MIPA, Universitas Negeri Malang \\ Jl. Semarang 5, Malang 65145, Jawa Timur \\ e-mail: zakytatsar1000@gmail.com
}

\begin{abstract}
We have developed a FIDTI (Fluid Isomorphic Diagnostic Test Inventory) as misconception diagnostic instruments. This development research is based on the importance of educators knowing the misconceptions of learners. Beside that the accurate quantity of diagnostic tests to help learners and educators understand the misconceptions that occur in the fluid material is still small.The model that used in this research FIDTI development is ADDIE (Analysis, Design, Development, Implementation, and Evaluation) development model. We use four steps of ADDIE development model. Four of these stages are deemed to be sufficiently adapted to the circumstances and eligibility. The product of this research is diagnostic assessment instrument of multiple choice which has four options with only one option is true and the other options are false. The options of products are developed based on student answer at essay question that has done before the product was developed. The products consist of 9 isomorphics that one isomorphic is consisting of three questions presented in a different form, but finished with the same concept (isomorphic). The number of indicators and subject topics which have respectively developed have 44,4\% and 53,6\% more than the previsiouse research. FIDTI is suitable to diagnostie student misconseption's about fluids with validity test scores of 3,6 from 4. Diagnostic conception product in the study is using two criterias. Based on analysis data, the mean accuracy of the first criteria and the accuracy of the second criteria are 73,8\% and $68,9 \%$.
\end{abstract}

Keywords :FIDTI, Misconception, ADDIE

\begin{abstract}
Abstrak: Telah dilakukan penelitian pengembangan FIDTI (Fluid Isomorphic Diagnostik Test Inventory) sebagai instrumen diagnostik miskonsepsi fluida. Penelitian pengembangan ini didasarkan pada pentingnya pendidik mengetahui miskonsepsi peserta didik serta kuantitas tes diagnostik yang akurat untuk membantu peserta didik dan pendidik dalam memahami miskonsepsi yang terjadi pada materi fluida masih sedikit. Adapun model yang digunakan dalam penelitian pengembangan FIDTI adalah model pengembangan ADDIE (Analysis, Design, Development, Implementation, dan Evaluation). Produk yang dikembangkan merupakan instrumen penilaian diagnostik dengan karakteristik berbentuk tes objektif pilihan ganda yang memiliki empat pilihan jawaban dengan satu pilihan jawaban benar dan pilihan jawaban lainnya merupakan jawaban salah. Pilihan jawaban produk dikembangkan berdasarkkan jawaban subjek uji coba menggunakan soal uraian yang telah telah dilakukan sebelum produk dikembangkan. Produk yang dikembangkan memiliki kuantitas indikator dan subjek penelitian masing-masing 44,4 \% dan 53,6\% lebih banyak dibandingkan dengan penelitian sebelumnya.Instrumen FIDTI layak digunakan untuk mendeteksi miskonsepsi peserta didik dengan skor uji validitas sebesar 3,6 dari skor 4. Adapun diagnosis konsepsi produk pada penelitian pengembangan ini menggunakan dua kriteria. Setelah dilakukan analisis hasil uji coba produk diperoleh tingkat rata-rata persentase keakuratan keakuratan diagnosis secara keseluruhan dengan menggunakan kriteria pertama dan kedua masing-masing sebesar $73,8 \%$ dan $68,9 \%$.
\end{abstract}

Kata Kunci : FIDTI, Miskonsepsi, ADDIE 


\section{PENDAHULUAN}

Pemahaman konsep merupakan sesuatu yang penting dan harus dikuasai oleh peserta didik. Konsep dalam fisika bertujuan agar peserta didik dapat menjelaskan fenomena-fenomena alam baik yang terjadi di lingkungan sekitar maupun di luar. Apabila konsepsi yang dimiliki peserta didik tidak sesuai dengan konsep-konsep fisika, maka dapat menyebabkan miskonsepsi yang berdampak negatif terhadap hasil belajar peserta didik apabila terus digunakan oleh peserta didik.

Sebelum kegiatan pembelajaran, pendidik perlu mengetahui informasi miskonsepsi pada peserta didik dengan memberikan tes diagnostik. Tes diagnostik merupakan salah satu bentuk penilaian formatif yang bertujuan untuk mengetahui konsep dan pemahaman pembelajaran yang dimiliki peserta didik, mengidentifikasi kelebihan, mendia-gnosis kelemahan, dan sebagai sumber informasi yang dapat digunakan oleh pendidik dalam memperbaiki pembelajaran dan digunakan peserta didik untuk mengetahui tingkat pemahaman konsep yang dimiliki serta mem-perbaiki prestasi mereka (Warner, 2011). Hasil tes diagnostik juga dapat menjadi dasar bagi pendidik merancang kegiatan pembelajaran yang hendak dilakukan.

Tes diagnostik konseptual pada materi fluida sangat dibutuh-kan. Hal tersebut diperoleh berdasarkan beberapa pernyataan peserta didik kelas XI SMA dan MA di Kota dan Kabupaten Malang yang menjadi responden dalam wawancara yang dilakukan peneliti mengungkapkan bahwa mereka membutuhkan tes yang dapat mendiagnosis pemaha-man mereka terhadap materi fisika serta dapat memberikan umpan balik. Hasil yang sama juga diperoleh dari hasil wawancara dengan salah satu guru fisika di SMA Negeri 6 Malang yang menyatakan bahwa tes diagnostik sangat dibutuhkan oleh guru dalam rangka memahami miskonsepsi yang dialami oleh peserta didik.

Kuantitas tes diagnostik yang akurat untuk membantu peserta didik dan pendidik dalam memahami miskonsepsi yang terjadi pada materi fluida masih sedikit. Docktro dan Mestre (2014:24) menjelaskan bahwa terdapat 30 lebih tes diagnostik konseptual fisika yang telah dibuat dan hanya setengahnya yang telah dipublikasikan, sedangkan selebihnya masih dalam pengem-bangan dan proses validasi. Tes diagnostik konseptual fisika yang telah divalidasi dan dipublikasikan diantaranya: MDT, MBT, FCI, FMCE , TUG-K, CSEM, DIRECT, BEMA, R-FCI, QMCS, CUE, FVA. Tes diagnostik konseptual yang telah divalidasi dan dipublikasikan tersebut sebagian besar pada materi elektromagnetik, kinematika, dan dinamika. Selain itu sebagian besar masih berupa tes pilihan ganda satu tingkat yang kemungkinan besar peserta didik hanya menebak dalam menjawabnya.

Berdasarkan studi literatur, tes berbentuk pilihan ganda yang berkaitan dengan materi fluida telah dikembangkan oleh beberapa peneliti. Goszewski et al (2013) mengembangkan tes konseptual ber-bentuk pilihan ganda untuk menge-ksplorasi kesulitan peserta didik dalam memahami konsep tekanan hidrostatis. Wagner et al (2013) mengembangkan tes konseptual berbentuk pilihan ganda untuk mengeksplorasi kesulitan peserta didik dalam memahami konsep gaya angkat ke atas pada fluida. Heron dan Kautz (2003) mengungkapkan miskonsepsi-miskonsepsi peserta didik terkait hukum Archimedes. Sahin et al (2010) mengungkapkan bahwa ditemukan miskonsepsi peserta didik terkait fluida yaitu tekanan fluida yang dialami oleh objek di dasar wadah yang bagian bawahnya menyempit seperti bentuk trapesium terbalik lebih besar dibandingkan tekanan yang dialami benda di dasar wadah yang bagian bawahnya datar (seperti bentuk silinder). Semua penelitian tersebut mengembangkan soal pilihan ganda satu jenis yang masih memungkinkan peserta didik menjawab hanya dengan asal menebak. Selain itu materi yang digunakan hanya terdiri dari masing-masing sub materi dari materi fluida. 
Tes diagnostik penelitian ini adalah berbentuk soal isomorfik. Soal isomorfik merupakan bentuk soal dimana dalam satu indikator butir soal terdiri dari 3 butir soal yang tampak berbeda, namun diselesaikan dengan prinsip yang sama. Menurut Singh (2008) soal isomorfik adalah soal yang mampu mendiagnosis konsepsi peserta didik. Solehudin (2016:69) mengembangkan tes diagnostik isomorfik untuk mengetahui miskonsepsi pada materi fluida. Namun dalam penelitian tersebut masih menggu-nakan indikator dan subjek penelitian yang relatif sedikit. Penelitian ini menggunakan indikator yang lebih banyak dan subjek penelitian yang lebih banyak, sehingga memungkinkan untuk lebih digeneralisasi penggunaannya.

\section{METODE PENELITIAN}

Penelitian ini merupakan penelitian pengembangan yang menggunakan model pengembangan ADDIE yang dikembangkan oleh Reisner dan Mollenda terdiri dari lima langka yaitu (1) Analysis, (2) Design, (3) Development, (4) Implementation, dan (5) Evaluate. Dalam penelitian ini hanya diguna-kan empat tahap pertama dengan alasan empat tahap tersebut dinggap cukup disesuaikan dengan keadaan dan kelayakan.

\subsection{Analysis}

Tahap analysis merupakan tahap awal atau persiapan untuk pengembangan. Tahap ini terdiri atas dua langkah, yaitu studi kepustakaan dan studi lapangan. Analisis miskonsepsi yang sering dialami oleh peserta didik pada materi fluida dilakukan dengan mengkaji jurnal dari Goszewski et. al (2013) tentang Exploring Student Difficulties with Pressure in a Fluid, Wagner et. al (2013) tentang Exploring Student Difficulties with Buoyancy, Heron dan Suskavcevic (2005) tentang Pre- Service Teachers' Understanding of Static of Fluids. Miskonsepsi-miskonsepsi dikumpulkan dan digunakan untuk menentukan indikator mana yang tepat untuk mengidentifikasi miskonsepsi fluida sesuai lingkup materi peserta didik Indonesia. Studi lapangan dilakukan dengan cara observasi dan wawancara terhadap guru SMAN 6 Malang dan beberapa peserta didik dari beberapa SMA dan MA di Kota dan Kabupaten Malang dengan tujuan mengetahui proses asesmen yang dilakukan guru di lapangan.

\subsection{Design}

Rancangan pengembangan produk dalam penelitian ini terdapat empat langkah kegiatan yaitu identifikasi tujuan instrumen dan ruang lingkup materi, menyusun soal uraian, review butir soal uraian, dan uji soal uraian. Identifikasi tujuan tes dan ruang lingkup materi dilakukan agar isi tes yang ditulis tidak keluar dari ruang lingkup materi yang telah ditentukan dan tidak ada bagian penting dari materi yang terlewatkan dalam tes. Butir soal uraian yang digunakan untuk menjaring sebaran konsepsi peserta didik yang akan digunakan sebagai pilihan jawaban.

\subsection{Develop}

Tahap pengembangan draft instrumen diagnostik FIDTI diawali dengan menganalisis jawaban peserta didik berdasarkan tes menggunakan soal uraian. Soal pilihan ganda yang disusun menggunakan empat pilihan jawaban dengan hanya ada satu jawaban yang paling benar. Tiga pilihan jawaban yang lain merupakan distraktor yang disusun berdasarkan pemetaan miskonsepsi peserta didik hasil analisis jawaban peserta didik pada pengujian soal uraian. Kriteria dalam menetukan distraktor pada FIDTI adalah:

i. Jawaban yang paling banyak dijawab peserta didik.

ii. Jawaban yang masuk akal dan sesuai dengan pemikiran peserta didik 
iii. Apabila ada beberapa peserta didik yang menjawab dengan kalimat yang berbeda tetapi intinya sama, maka dapat dirumuskan menjadi satu kalimat dengan arti/makna yang sama. Draft Instrumen tes diagnostik FIDTI yang dikembangkan kemudian divalidasi isi oleh dosen ahli dan guru. Hasil validasi isi kemudian digunakan untuk merevisi draf instrumen sebelum diimplementasi-kan.

\subsection{Implement}

Soal yang telah direvisi berdasarkan penilaian dan saran dari ahli selanjutnya diujicobakan kepada subjek coba. Setelah hasil uji coba terbatas didapatkan, dilakukan analisis miskonsepsi. Selanjutnya analisis miskonsepsi dilakukan untuk mengidentifikasi peserta didik yang memiliki pemahaman konsep baik, peserta didik yang lemah pemahaman konsepnya, peserta didik yang meng-alami miskonsepsi, dan peserta didik yang tidak paham konsep, serta jenis miskonsepsi peserta didik pada materi fluida.

Diagnosis konsepsi pada tiga subjek uji coba yakni peserta didik kelas XI SMAN 6 Malang, peserta didik kelas XI MA Ma'arif Singosari dan peserta didik kelas XI SMAN 7 Malang dilakukan menggunakan dua kriteria. Kriteria pertama adalah subjek uji coba akan teridentifikasi memiliki konsepsi apabila ketiga jawabannya pada masing-masing butir soal dalam isomorfik yang sama konsisten, jika tidak maka subjek akan teridentifikasi tidak memiliki konsistensi konsepsi. Kriteria kedua adalah subjek uji coba akan teridentifikasi memiliki konsepsi apabila minimal dua dari ketiga jawabannya pada masing-masing butir soal dalam isomorfik yang sama konsisten, jika tidak maka subjek akan teridentifikasi tidak memiliki konsistensi konsepsi.

\section{HASIL DAN PEMBAHASAN}

Hasil diagnosis FIDTI berdasarkan jawaban subjek uji coba pada uji coba terbatas. Hasil diagnosis yang disajikan dari dua kriteria yang digunakan.

\subsection{Miskonsepsi Subjek tentang Tekanan Hidrostatis Benda dalam Fluida dengan Massa Jenis Berbeda}

Hasil identifikasi FIDTI pada isomorfik 1 dengan subek uji secara keseluruhan memberikan sebaran kategori konsepsi yang cukup variatif sebagai berikut. Pada kriteria pertama diperoleh hasil yaitu sebagian besar subjek terdiagnosis tidak paham konsep yaitu sebesar $49 \%, 1 \%$ subjek yang memiliki konsepsi kategori level 1 dan 3, $43 \%$ subjek memiliki konsepsi kategori level 2, serta $7 \%$ subjek memiliki konsepsi benar.

Pada kriteria kedua sebagian besar subjek terdiagnosis memiliki konsepsi level 2 dengan persentase sebesar $44 \% .23 \%$ subjek tidak memiliki konsistensi konsepsi, $3 \%$ subjek memiliki konsepsi kategori level 1 dan 3, serta $28 \%$ memiliki konsepsi benar. Sehingga dari kriteria pertama dan kedua dapat disimpulkan bahwa secara rata-rata subjek mengalami miskonsepsi level 2 yaitu subjek memiliki konsepsi bahwa tekanan hidrostatis hanya bergantung pada kedalaman benda/titik diukur dari dasar bejana.

\subsection{Miskonsepsi Subjek tentang Konsep Paradoks Tekanan Hidrostatik}

Hasil identifikasi FIDTI pada isomorfik 2 dengan subek uji secara keseluruhan memberikan sebaran kategori konsepsi yang cukup variatif sebagai berikut. Pada kriteria pertama diperoleh hasil yaitu sebagian besar subjek terdiagnosis tidak paham konsep yaitu sebesar $49 \%$, tidak ada subjek yang memiliki konsepsi kategori level 1dan 3, $41 \%$ subjek yang memiliki konsepsi kategori level 2, serta $11 \%$ subjek memiliki konsepsi benar.

Pada kriteria kedua sebagian besar subjek terdiagnosis memiliki konsepsi level 2 dengan persentase sebesar $44 \%$. $23 \%$ subjek tidak memiliki konsistensi konsepsi, $3 \%$ subjek 
memiliki konsepsi kategori level 1 dan 3, serta $27 \%$ memiliki konsepsi benar. Sehingga dari kriteria pertama dan kedua dapat disimpulkan bahwa secara rata-rata subjek mengalami miskonsepsi level 2 yaitu Subjek memiliki konsepsi bahwa tekanan hidrostatis yang dialami benda/titik bergantung pada banyaknya zat cair di dalam bejana.

\subsection{Miskonsepsi Subjek tentang Konsep Mengaplikasikan Hukum Utama Hidrostatika Pada Kehidupan Sehari-Hari}

Hasil identifikasi FIDTI pada isomorfik 3 dengan subek uji secara keseluruhan memberikan sebaran kategori konsepsi yang bertolak belakang yaitu terjadi kenaikan dan peurunan pada kriteria dua dan kriteria satu. Pada kriteria kedua terjadi penurunan yang signifikan subjek yang terdiagnosis tidak paham konsep dari $53 \%$ menjadi $15 \%$ dan kenaikan yang signifikan subjek yang memiliki konsepsi benar dari $47 \%$ menjadi $85 \%$. Serta tidak terdapat subjek yang memiliki konsepsi level 1, 2, dan 3 pada masing masing kriteria.

\subsection{Miskonsepsi Subjek tentang Konsep Menentukan Gaya Angkat Benda Dalam Suatu Fluida}

Hasil identifikasi FIDTI pada isomorfik 4 dengan subek uji secara keseluruhan memberikan sebaran kategori konsepsi sebagai berikut. Pada kriteria pertama dan kedua diperoleh hasil yaitu sebagian subjek terdiagnosis memiliki konsepsi level 1 yaitu terdiagnosis memiliki pemikiran bahwa subjek memiliki konsepsi bahwa besar gaya angkat fluida relatif terhadap dasar bejana dengan persentase masing-masing sebesar $56 \%$ dan $63 \%$.

\subsection{Miskonsepsi Subjek tentang Konsep Hukum Archimedes dalam Kehidupan Sehari- Hari}

Hasil identifikasi FIDTI pada isomorfik 5 dengan subek uji secara keseluruhan pada kriteria 1 dan kriteria 2, secara merata sebagian besar subjek mengalami miskonsepsi kategori level 2 yaitu terdiagnosis memiliki pemikiran bahwa semakin banyak es batu akan lebih cepat mencair (akan lebih cepat tumpah). Adapun persentase masing - masing kriteria adalah sebesar $54 \%$ dan $62 \%$.

\subsection{Miskonsepsi Subjek tentang Konsep Hukum Pascal}

Hasil identifikasi FIDTI pada isomorfik 6 dengan subek uji secara keseluruhan pada kriteria 1 dan kriteria 2 membe-rikan sebaran kategori konsepsi secara merata sebagian besar subjek mengalami miskonsepsi level 1yaitu subjek memiliki konsepsi bahwa besar gaya tekan yang dibutuhkan untuk menyeimbangkan beban pada bejana berhubungan berbanding lurus dengan banyaknya luasan yang digunakan. dengan masing-masing persentase sebesar $50 \%$ dan $55 \%$.

\subsection{Miskonsepsi Subjek tentang Konsep Konsep Kontinuitas Pada Fluida Dinamik Dalam Kehidupan Sehari-Hari}

Hasil identifikasi FIDTI pada isomorfik 7 dengan subek uji secara keseluruhan pada kriteria 1dan kriteria 2 memberikan sebaran kategori konsepsi secara merata sebagian besar subjek mengalami miskonsepsi level 1 yaitu subjek memiliki konsepsi bahwa aliran fluida berbenading lurus dengan luas penampang aliran fluida karena luas penampang aliran fluida sebanding dengan debit fluida dengan masing-masing persentase sebesar $57 \%$ dan $71 \%$.

\subsection{Miskonsepsi Subjek tentang Konsep Hukum Bernoulli}

Hasil identifikasi FIDTI pada isomorfik 8 dengan subek uji secara keselu-ruhan memberikan sebaran kategori konsepsi sebagai berikut. Pada kriteria pertama sebagian besar 
subjek terdiagnosis tidak memiliki konsistensi konsepsi sebesar $50 \%$. Sedangkan pada kriteria kedua sebagian besar subjek terdiagnosis miskonsepsi level 2 yaitu dengan persentase sebesar $50 \%$. Namun secara merata pada kriteria 1 dan 2 sebagian besar subjek mengalami miskonsepsi level 2 yaitu subjek memiliki konsepsi bahwa tinggi fluida dalam pipa bergantung pada jarak pipa dengan blower (semakin dekat dengan blower, maka semakin besar tinggi fluida).

\subsection{Miskonsepsi Subjek tentang Konsep Hukum Bernoulli Pada Fluida Dinamik Dalam Kehidupan Sehari-Hari}

Hasil identifikasi FIDTI pada isomorfik 9 dengan subek uji secara keseluruhan memberikan sebaran kategori konsepsi sebagai berikut. Pada kriteria pertama sebagian besar subjek terdiagnosis tidak memiliki konsistensi konsepsi sebesar $73 \%$ begitu juga pada kriteria kedua, sebagian besar subjek terdiagnosis tidak memiliki konsistensi konsepsi walaupun mengalami penurunan dibandingkan dengan kriteria kedua dengan persentase sebesar $51 \%$.

Hasil diagnostik FIDTI dapat dikatakan akurat jika kategori konsepsi subjek uji coba yang di-diagnostik FIDTI sesuai dengan kategori konsepsi yang benar-benar dialami subjek uji coba berdasarkan jawabannya pada soal uraian. Keakuratan hasil diagnostik FIDTI kriteria pertama dan kedua pada masing-masing isomorfik terhadap jawaban subjek uji coba pada soal uraian disajikan dalam bentuk persentase pada diagram berikut.

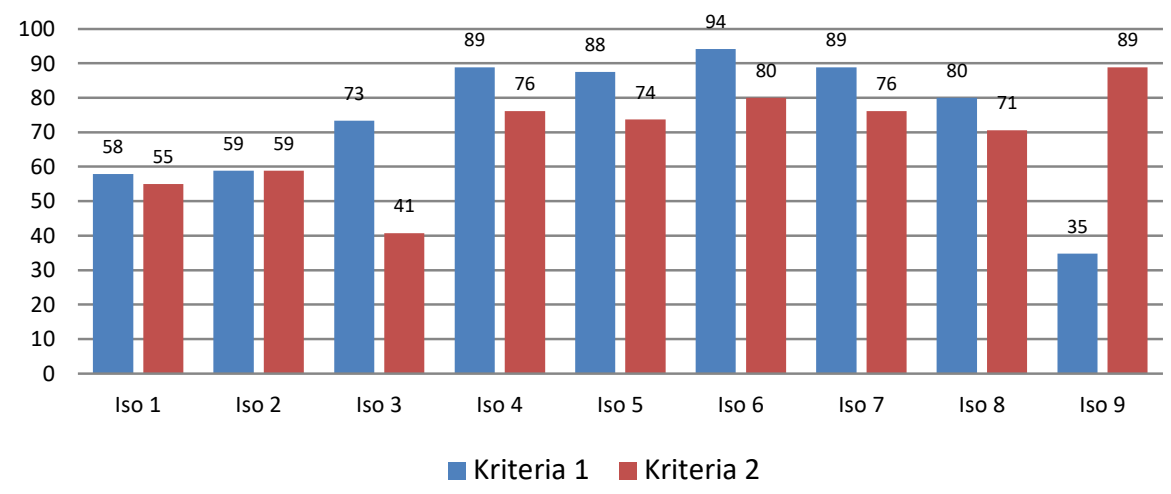

(a)

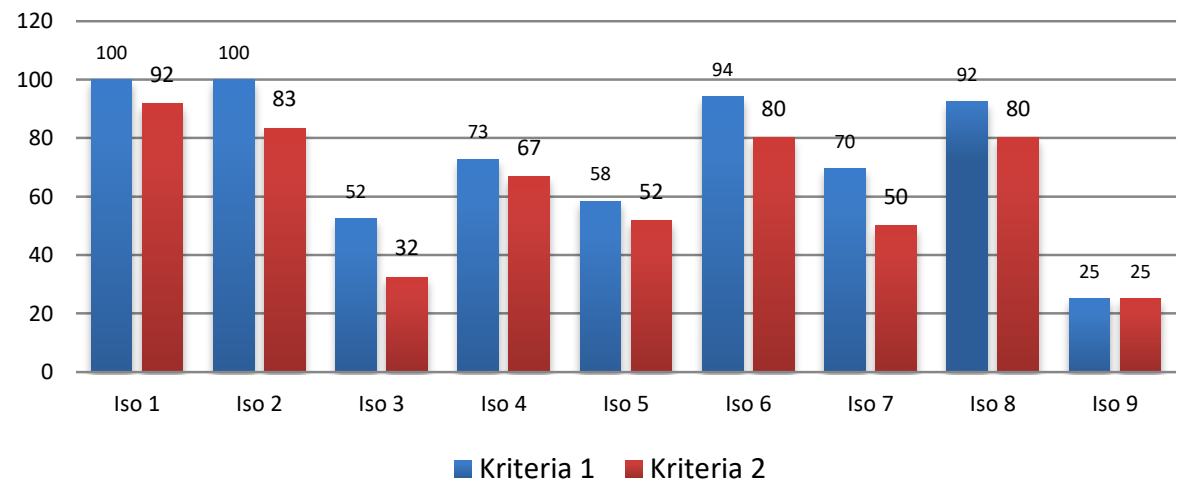

(b) 


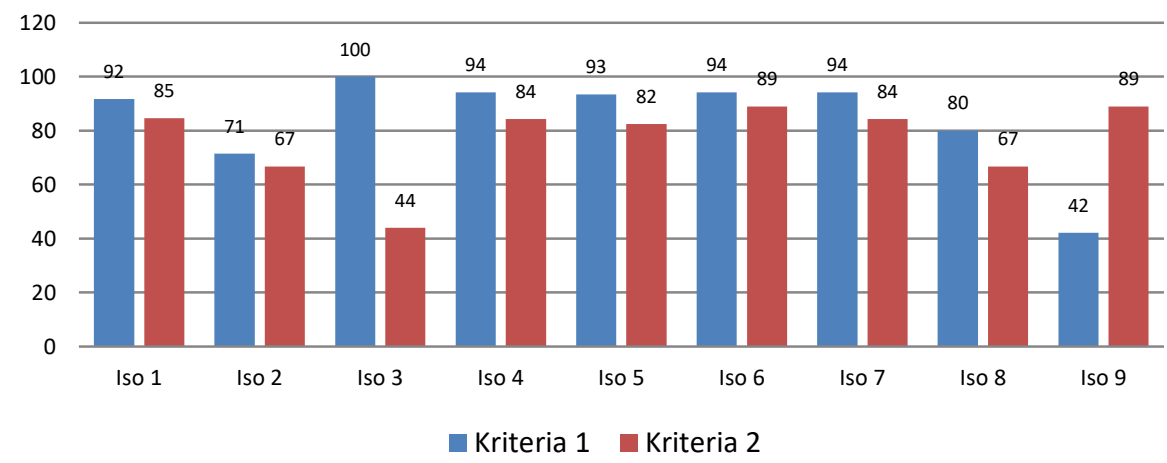

(c)

Gambar 1. Diagram Tingkat Keakuratan Hasil Isntrumen Diagnostik FIDTI Menggunakan Kriteria Pertama dan Kedua (a) Peserta didik Kelas XI MIA 4 SMAN 6 (b) Peserta didik Kelas XI IPA 2 MA Ma'arif Singosari (c) Peserta didik Kelas XI MIA 6 SMAN 7

Berdasarkan Gambar 1. tampak bahwa tingkat keakuratan hasil instrumen diagnostik FIDTI menggunakan kriteria pertama lebih tinggi dibandingkan dengan kriteria kedua. Adapun perubahan tingkat keakuratan hasil instrumen diagno-stik FIDTI pada masing-masing subjek uji coba adalah sebagai berikut.

\section{a. Peserta Didik Kelas XI MIA 4 SMAN 6 Malang}

Pada isomorfik 1 tingkat keakuratan dengan menggunakan kriteria pertama diperoleh persentase sebesar $58 \%$ dan sedikit turun menjadi $55 \%$ ketika menggunakan kriteria 2 . Pada isomorfik 2 tingkat keakuratan dengan menggunakan kriteria pertama dan kriteria kedua diperoleh persentase yang sama sebesar $59 \%$. Pada isomorfik 3 tingkat keakuratan mengalami penurunan yang signifikan. Pada kriteria pertama diperoleh persentase sebesar 73 \% sedangkan pada kriteria kedua diperoleh sebesar $55 \%$. Pada isomorfik 4, 5, 6, 7, dan 8 terjadi penurunan tingkat keaku-ratan dari kriteria pertama menuju kriteria kedua secara berturut-turut yaitu $89 \%$ menjadi $76 \%, 88 \%$ menjadi $74 \%, 94 \%$ menjadi $80 \%, 89 \%$ menjadi $76 \%$, dan $80 \%$ menjadi $71 \%$. Sedangkan pada Isomorfik 9 terjadi kenaikan tingkat keakuratan dari kriteria 1 menuju kriteria 2 yaitu dari $35 \%$ menjadi $89 \%$.

\section{b. Peserta Didik Kelas XI IPA 2 MA Ma'arif Singosari}

Adapun tingkat keakuratan pada isomorfik1, 2, 3, 4, 5, 6, 7, dan 8 terjadi penurunan tingkat keakurat-an dari kriteria 1 menuju kriteria 2 secara berturut-turut yaitu $100 \%$ menjadi $92 \%$, $100 \%$ menjadi $83 \%$, $52 \%$ menjadi $32 \%$, $73 \%$ menjadi $67 \%$, $58 \%$ menjadi $52 \%, 94 \%$ menjadi $80 \%, 70 \%$ menjadi $50 \%$,dan $92 \%$ menjadi $80 \%$. Sedangkan pada Isomorfik 9 terjadi tidak terjadi kenaikan maupun penurunan tingkat keakuratan dari kriteria 1 menuju kriteria 2 yaitu diperoleh persentase yang sama sebesar $25 \%$.

\section{c. Peserta Didik Kelas XI MIA 6 SMAN 7 Malang}

Adapun tingkat keakuratan pada isomorfik1, 2, 3, 4, 5, 6, 7, dan 8 terjadi penurunan tingkat keakuratan dari kriteria 1 menuju kriteria 2 secara berturut-turut yaitu $92 \%$ menjadi $85 \%, 71$ $\%$ menjadi $67 \%, 100 \%$ menjadi $44 \%$, $94 \%$ menjadi $84 \%$, $93 \%$ menjadi $82 \%, 94 \%$ menjadi $89 \%$, $94 \%$ menjadi $84 \%$,dan $80 \%$ menjadi $67 \%$. \%. Sedangkan pada Isomorfik 9 terjadi kenaikan tingkat keakuratan dari kriteria 1 menuju kriteria 2 yaitu dari $42 \%$ menjadi $89 \%$. 


\section{KESIMPULAN DAN SARAN}

Berdasarkan hasil analisis jawaban peserta didik dengan subjek peserta didik kelas XI MIA 4 SMAN 6 Malang, kelas XI MA Ma'arif Singosari, kelas XI MIA 6 SMAN 7 Malang secara keseluruhan menunjukkan bahwa pada kriteria pertama sebagian besar subjek terdiagnosis tidak memiliki konsis-tensi konsepsi. Sedangkan pada kriteria kedua sebagian besar masih mengalami miskonsepsi Terkait fluida.

Miskonsepsi peserta didik pada materi fluida yang berhasil diketahui menggunakan instrumen tes diagnostik FIDTI adalah subjek memiliki konsepsi bahwa tekanan hidrostatis hanya bergantung pada kedalaman benda atau titik diukur dari dasar bejana, peserta didik memiliki konsepsi bahwa tekanan hidrostatis yang dialami benda/titik bergantung pada banyaknya zat cair di dalam bejana, subjek memiliki konsepsi bahwa besar gaya angkat fluida relatif terhadap dasar bejana, peserta didik memiliki konsepsi bahwa semakin banyak es batu, apabila mencair maka volume zat cair semakin bertambah, subjek memiliki konsepsi bahwa besar gaya tekan yang dibutuhkan untuk menyeimbangkan beban pada bejana berhubungan sebanding dengan banyaknya luasan yang digunakan, peserta didik memiliki konsepsi bahwa aliran fluida sebanding dengan luas penampang aliran fluida karena luas penampang aliran fluida sebanding dengan debit fluida, dan peserta didik memiliki konsepsi bahwa tinggi fluida dalam pipa bergantung pada jarak pipa dengan blower (semakin dekat dengan blower, maka semakin besar tinggi fluida), dan

Hasil diagnosis FIDTI meng-gunakan kriteria pertama menunjuk-kan tingkat keakuratan yang lebih tinggi di semua isomorfik pada ketiga subjek uji coba. Hasil diagnosis FIDTI yang dilakukan menggunakan kriteria pertama juga memiliki kecocokan yang lebih tinggi dengan respon subjek uji coba pada soal uraian daripada hasil diagnosis FIDTI yang dilakukan menggunakan kriteria kedua.

\section{DAFTAR PUSTAKA}

Warner, Zachary B. 2011. Adoption of Computer-Based Formative Assessment in a High School Mathematics Classroom. Journal of Cases on Information Technology, 13 (4):9-20.

Docktor, Jennifer L, ang Mestre, Jose P. 2014. Synthesis of Discipline Based Education Research in Physics. Physical Review Special Topics-Physics Education Research. 10,020119 (58): 24.

Goszewski, M., Bazan, Z. \& Wagner, D.J. 2013. Exploring Student Difficulties with Pressure in a Fluid. PERC Proceedings, Published by the American Association of Physics Teachers under a Creative Commons Attribution.

Wagner, D.J., Carboe, E. \& Lindow, A.2013. Exploring Student Difficulties with Bouyancy. PERC Proceedings, Pubished by the American Association of Physics Teachers under a Creative Commons Attribution.

Heron, P. \& Kautz, C. 2003. Helping Students Develop an Understanding of Archimedes Principle, Part I: Research on student understanding. American Journal of Physics, 71 (11): 1178-1187

Sahin, et all. 2010. Exploring Student Difficulties with bouyoncy. PERC Proceedings, Published by the American Association of Physics Teachers under a Creative Commons Attribution.

Singh, C. 2008. Assessing Student expertise in introductory physics with isomorfikmorphic problem. II.Effect of some potential factors on problem solving and transfer. 
Physical Review Special Topics - Physics Education Research, 4(1), 1-10. (online), http://doi.org/10.1103/PhysRevSTPER,4.010105 diakses 11 Desember 2016.

Solehudin. 2016. Pengembangan FDT (Fluid Diagnostic Test) Sebagai Instrumen Diagnostik Miskonsepsi Peserta didik Pada Materi Fluida.FMIPA UM. 